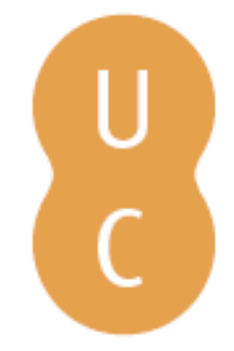

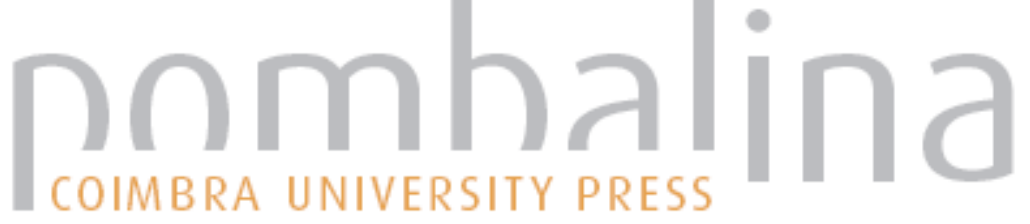

\section{Comparative study of 15 STR forensic loci between a Bolivian population and Central and South America populations}

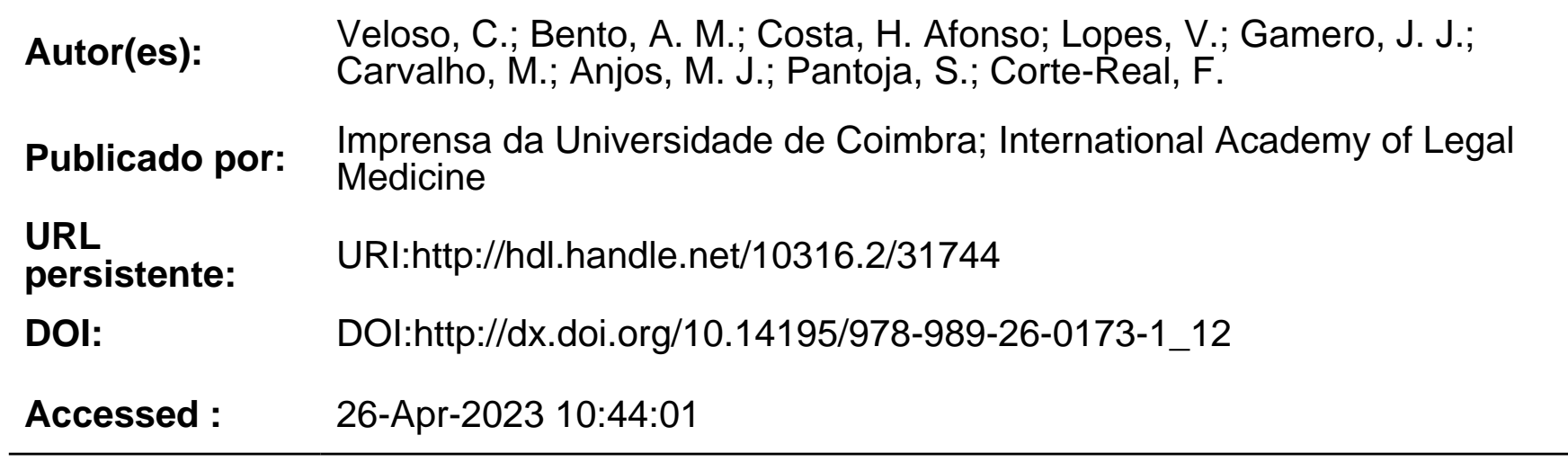

A navegação consulta e descarregamento dos títulos inseridos nas Bibliotecas Digitais UC Digitalis, UC Pombalina e UC Impactum, pressupõem a aceitação plena e sem reservas dos Termos e Condições de Uso destas Bibliotecas Digitais, disponíveis em https://digitalis.uc.pt/pt-pt/termos.

Conforme exposto nos referidos Termos e Condições de Uso, o descarregamento de títulos de acesso restrito requer uma licença válida de autorização devendo o utilizador aceder ao(s) documento(s) a partir de um endereço de IP da instituição detentora da supramencionada licença.

Ao utilizador é apenas permitido o descarregamento para uso pessoal, pelo que o emprego do(s) título(s) descarregado(s) para outro fim, designadamente comercial, carece de autorização do respetivo autor ou editor da obra.

Na medida em que todas as obras da UC Digitalis se encontram protegidas pelo Código do Direito de Autor e Direitos Conexos e demais legislação aplicável, toda a cópia, parcial ou total, deste documento, nos casos em que é legalmente admitida, deverá conter ou fazer-se acompanhar por este aviso.

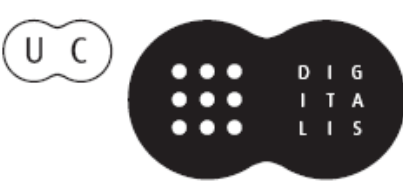




\section{Duarte Nuno Vieira Anthony Busuttil \\ Denis Cusack • Philip Beth}
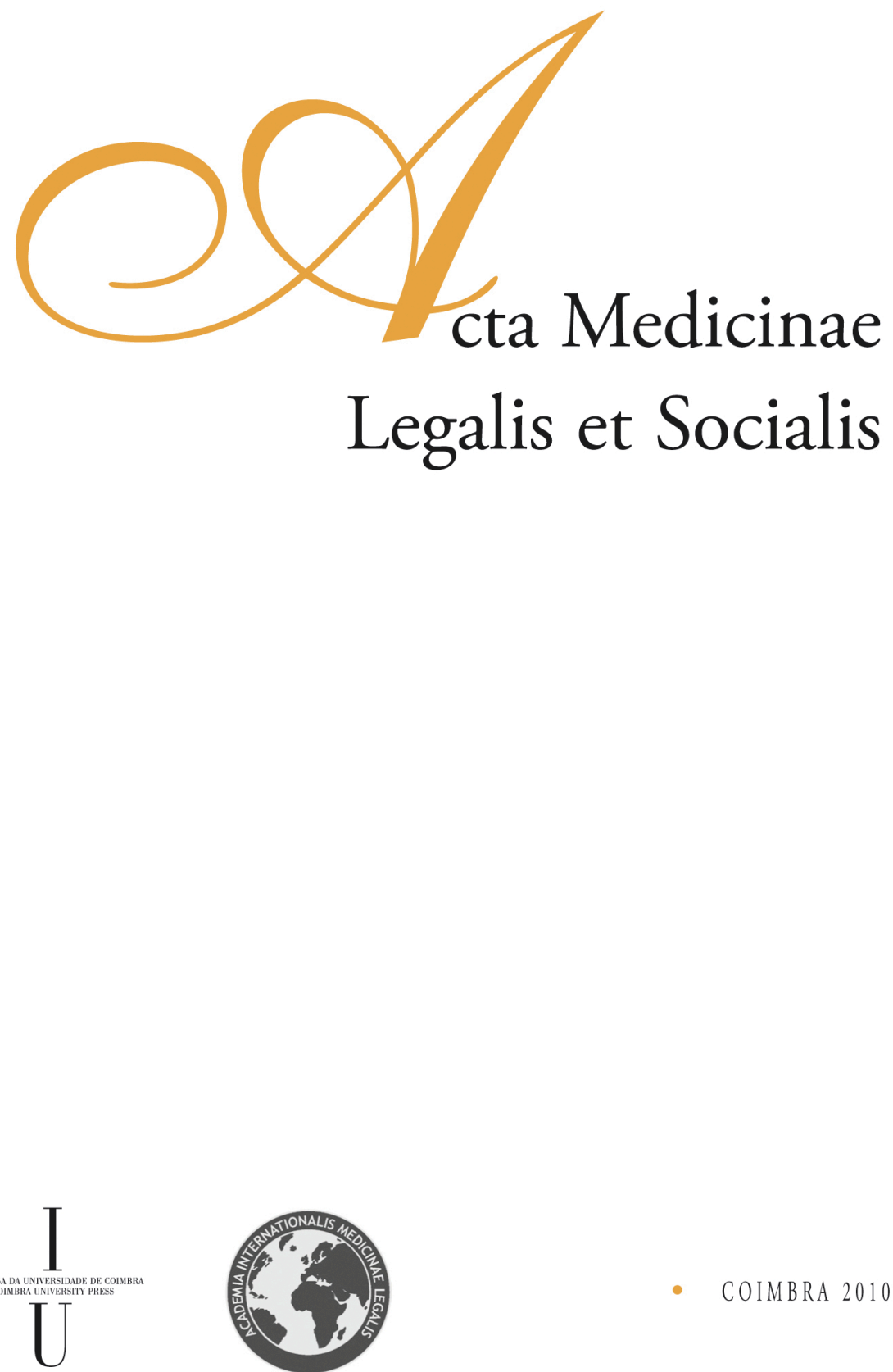
C. Veloso ${ }^{1}$, A. M. Bento ${ }^{1}$, H. Afonso Costa ${ }^{1}$, V. Lopes ${ }^{1}$, J. J. Gamero ${ }^{2}$, M. Carvalho ${ }^{1}$, M. J. Anjos ${ }^{1}$, S. Pantoja ${ }^{3}$, F. Corte-Real ${ }^{4,5}$

${ }^{1}$ Forensic Genetic Service, Centre Branch of the National Institute of Legal Medicine, Coimbra, Portugal

${ }^{2}$ Department of Legal Medicine, Faculty of Medicine, University of Cadiz, Spain

3 University of La Paz, Bolivia

${ }^{4}$ National Institute of Legal Medicine, Coimbra, Portugal

${ }^{5}$ Faculty of Medicine, University of Coimbra, Portugal

\title{
COMPARATIVE STUDY OF 15 STR FORENSIC LOCI BETWEEN A BOLIVIAN POPULATION AND CENTRAL AND SOUTH AMERICA POPULATIONS
}

\begin{abstract}
A population of 117 individuals of La Paz was typed for 15 STR loci using the AmpFISTR $®$ Identifiler ${ }^{\mathrm{TM}}$ PCR kit (Applied Biosystems). Allelic frequencies and parameters of forensic interest (power of discrimination and probability of exclusion) were calculated. A comparative study with populations from Central and South America was done, using the calculation of genetic distances between them and the phylogenetic tree.
\end{abstract}

\section{Introduction}

The study of autosomal short tandem repeats (STRs) in a Bolivian population from $\mathrm{La} \mathrm{Paz}$ is important since this is a country with a high genetic variability, according to previous studies made in mitochondrial DNA [1]. Allelic frequencies of 15 STR forensic loci (D8S1179, D21S11, D7S820, CSF1PO, D3S1358, TH01, D13S317, D16S539, D2S1338, D19S433, vWA, TPOX, D18S51, D5S818 e FGA) were calculated in a sample from $\mathrm{La} \mathrm{Paz}$ and a comparative study with other populations from Central and South America [2-11] was done.

\section{Material and Methods}

DNA from 117 unrelated healthy individuals of La Paz, Bolivia was extracted, using Chelex100 method [12]. Samples were amplified using the AmpFISTR® Identifiler ${ }^{\mathrm{TM}}$ PCR kit (Applied Biosystems) [13] according to manufacturer's instructions. Amplified products were separated and detected using an ABI Prism ${ }^{\mathrm{TM}} 310$ Genetic Analyzer (Applied Biosystems), analyzed with GeneScan software version 3.1. and typed using the reference sequenced ladder.

Allelic frequencies (see table 1), observed and expected heterozygosity and HardyWeinberg (HW) equilibrium were calculated using the Arlequin population genetics software v3.1 [14]. Matching probability, power of discrimination and power of exclusion were achieved using the PowerStats v1.2 software. Software Phylip v3.5c [15] was used to establish phylogenetic relationships between population of $\mathrm{La} \mathrm{Paz}$ and other Central and South American populations, by calculating the genetic distances. 
Neighbor-Joining method produced the phylogenetic tree, visualized by application of software TreeView v1.6.6 [16].

\section{Results}

Results are founded in figure 1 , table 1 and table 2.

\section{Discussion}

This Bolivian population is in Hardy-Weinberg equilibrium for all markers, except for CSF1PO $(\mathrm{P}<0,05)$. The observed heterozygosity (Ho) is between 0.573 (D5S818) and 0,872 (FGA). The power of discrimination (PD) varies between 0.760 (TPOX) and 0.963 (FGA) and the combined power of discrimination for the 15 loci is 0.9999999 . The probability of exclusion (PE) varies between 0.259 (D5S818) and 0.738 (FGA), and the combined probability of exclusion for all loci is 0.999987 (see table 2).

Phylogenetic analysis (figure 1) revealed that La Paz is distant from the remaining populations, mainly the Brazilians, with genetic distances greater than 0.1319 . The population that reveals the smaller distance from La Paz population is Valley of Mexico (0.0381). Populations of El Salvador and Mexico have genetic distances of 0.0519 and 0.0439 respectively, Central region of Mexico (0.0719), Buenos Aires (0.0814), Caracas (0.1012) and Maracaibo-Venezuela (0.1031).

\section{Conclusions}

Our results are important to determine the genetic background of La Paz population and the combination of the studied 15 STR loci presents a powerful strategy for individual identification and parentage analysis.

The geographical situation of La Paz, namely the location at highlands around Lake Titicaca, could explain the higher genetic distances between other populations from Central and South American.

\section{References}

[1] COSTA, H.A., CARVALHO, M., LOPES, V. et al., Mitochondrial DNA sequence analysis of a native Bolivian population, J. Forensic Leg Med., Vol. 17(5), pp. 247-253, 2010.

[2] SANTOS, M.V., ANJOS, M.J., ANDRADE, L. et al., Population genetic data for the STR loci using the the AmpFISTR® Identifiler ${ }^{\mathrm{TM}}$ Kit in Bahia, Brazil, International Congress Series, Vol. 1261, pp. 219-222, 2004.

[3] MOrales, J.A., MOnTerrosa, J.C., PUEnTE, J., Population genetic data from El Salvador (Central America) using AmpFISTR ${ }^{\circledR}$ Identifiler ${ }^{\circledR}$ PCR Amplification Kit, International Congress Series, Vol 1261, pp. 223-225, 2004.

[4] Chiurillo, M.A., MORALES, A., MENDES, A.M., et al., Genetic profiling of a central Venezuelan population using 15 STR markers that may be of forensic importance, Forensic Sci Int, Vol 136, pp. 99-101, 2003.

[5] GOROSTIZA, A., GONZÁLEZ-MARTíN, A., RAMÍREZ, C.L. et al., Allele frequencies of the AmpFISTR® Identifiler ${ }^{\mathrm{TM}}$ loci in yhe population of Metztitlán (Estado de Hidalgo), México, Forensic Sci Int, Vol 166, pp. 230-232, 2007. 
[6] LUNA-VAZQUEZ, A., VILCHIS-DORANTES, G., AGUILAR-RUIZ, M.O., et al., Population data for 15 loci (Identifiler ${ }^{\circledR}$ Kit) in a simple from the Valley of Mexico, J. Leg. Med., Vol 7, pp. 331-333, 2005.

[7] BOZZO, W.R., PENA, M.A., ORTIZ, M.I., LOJO, M.M., Genetic data from Powerplex ${ }^{\circledR}$ 16 system and Identifiler ${ }^{\mathrm{TM}}$ kits from Buenos Aires province (Argentina), Legal Medicine, Vol 9, pp. 151-153, 2007.

[8] HERNÁNDEZ-GUTIÉRREZ, S., HERNÁNDEZ-FRANCO, P., MARTÍNEZ-TRIPP, S. et al., STR data for 15 loci in a population simple from the central region of Mexico, Forensic Sci Int, Vol 151, pp. 97-100, 2005.

[9] BERNAL, L.P., BORJAS, L., ZABALA, W. et al., Genetic variation of 15 STR autosomal loci in the Maracaibo population from Venezuela, Forensic Sci Int, Vol 161, pp. 60-63, 2006.

[10] GÓES, A.C.S., SILVA, D.A., GIL, É.H.F. et al., Allele frequencies data and statistic parameters for 16 STR loci - D19S433, D2S1338, CSF1PO, D16S539, D7S820, D21S11, D18S51, D13S317, D5S818, FGA, Penta E, TH01, vWA, D8S1179, TPOX, D3S1358 - in the Rio de Janeiro population, Brazil, Forensic Sci Int, Vol 140, pp. 131-132, 2004.

[11] BRITO, P. et al., Estudo de 15 STR's autossómicos (AmpFLSTR® Identifiler®) na população do estado do Amazonas (Brasil), IX Jornadas do GEP-ISFG, Manaus, 2 to 4 June of 2004.

[12] WALSH, P.S., METZGER, D.A., HIGUCHI, R., Chelex ${ }^{\circledR} 100$ as a Medium for Simple Extraction of DNA for PCR-Based Typing from Forensic Material, Biotechniques, Vol 10, No.4, pp. 506-513, 1991.

[13] AmpFISTR@ Identifiler ${ }^{\mathrm{TM}}$. Applied Biosystems.

[14] EXCOFFIER, L., Arlequin (Version3.1), 1995-2006.

[15] FELSENSTEIN, J., Phylip (Version 3.5c), University of Washington.

[16] RODERIC, D.M., Treeview (Version 1.6.6), 2001.

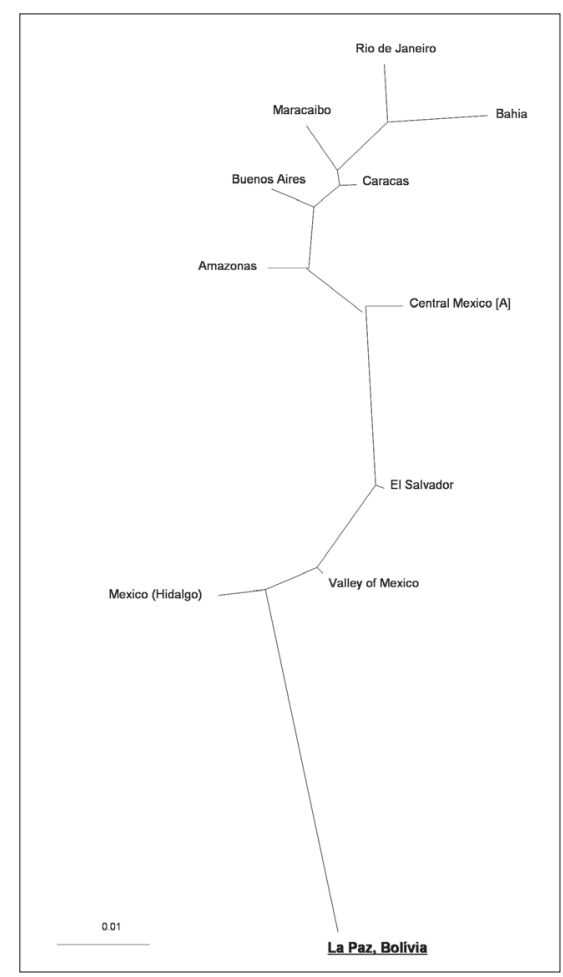

Figure 1 - Phylogenetic tree - genetic distances between Bolivia and other populations [1-10]; [A] Mestizos from the central region of Mexico. 


\begin{tabular}{|c|c|c|c|c|c|c|c|c|c|c|c|c|c|c|c|}
\hline Alleles & CSF1PO & D2S1338 & D3S1358 & D7S820 & D8S1179 & D13S317 & D16s539 & D19S433 & D21S11 & TH01 & vWA & TPOX & D18551 & D5S818 & FGA \\
\hline 6 & & & & & & & & & & 0,1880 & & & & & \\
\hline 7 & & & & 0,0170 & & & & & & 0,5170 & & & & 0,1370 & \\
\hline 8 & 0,0130 & & & 0,0210 & & 0,0260 & 0,0090 & & & 0,0560 & & 0,6030 & & 0,0040 & \\
\hline 9 & 0,0040 & & & 0,0380 & 0,0040 & 0,3590 & 0,2820 & & & 0,0340 & & 0,0210 & & 0,0850 & \\
\hline 9.3 & & & & & & & & & & 0,2010 & & & & & \\
\hline 10 & 0,2260 & & & 0,3080 & 0,0510 & 0,0980 & 0,2480 & & & 0,0040 & & 0,0300 & 0,0040 & 0,0040 & \\
\hline 11 & 0,2610 & & & 0,3720 & 0,0680 & 0,1580 & 0,1790 & 0,0040 & & & & 0,2090 & 0,0040 & 0,5850 & \\
\hline 12 & 0,4060 & & & 0,2220 & 0,0980 & 0,1750 & 0,1880 & 0,0260 & & & & 0,1320 & 0,1280 & 0,1410 & \\
\hline 12.2 & & & & & & & & 0,0170 & & & & & & & \\
\hline 13 & 0,0810 & & & 0,0210 & 0,3420 & 0,1200 & 0,0810 & 0,1370 & & & 0,0040 & 0,0040 & 0,1410 & 0,0430 & \\
\hline 13.2 & & & & & & & & 0,1840 & & & & & & & \\
\hline 14 & 0,0040 & & 0,0260 & & 0,2260 & 0,0640 & 0,0130 & 0,3500 & & & 0,0130 & & 0,2560 & & \\
\hline 14.2 & & & & & & & & 0,0260 & & & & & & & \\
\hline 15 & & & 0,4700 & & 0,1790 & & & 0,1710 & & & 0,0510 & & 0,1410 & & \\
\hline 15.2 & & & & & & & & 0,0510 & & & & & & & \\
\hline 16 & & 0,0170 & 0,3420 & & 0,0260 & & & 0,0210 & & & 0,3550 & & 0,1200 & & \\
\hline 16.2 & & & & & & & & 0,0090 & & & & & & & \\
\hline 17 & & 0,1240 & 0,1150 & & & & & 0,0040 & & & 0,4020 & & 0,1200 & & \\
\hline 18 & & 0,0680 & 0,0470 & & 0,0040 & & & & & & 0,1150 & & 0,0470 & & 0,0130 \\
\hline 19 & & 0,3460 & & & & & & & & & 0,0560 & & 0,0210 & & 0,1320 \\
\hline 20 & 0,0040 & 0,1450 & & & & & & & & & 0,0040 & & 0,0040 & & 0,0560 \\
\hline 21 & & 0,0170 & & & & & & & & & & & 0,0090 & & 0,0680 \\
\hline 22 & & 0,0130 & & & & & & & & & & & 0,0040 & & 0,0940 \\
\hline 23 & & 0,1880 & & & & & & & & & & & & & 0,1110 \\
\hline 24 & & 0,0510 & & & & & & & & & & & & & 0,1970 \\
\hline 25 & & 0,0260 & & & & & & & & & & & & & 0,1970 \\
\hline 26 & & 0,0040 & & & & & & & & & & & & & 0,1150 \\
\hline 27 & & & & & & & & & 0,0040 & & & & & & 0,0090 \\
\hline 28 & & & & & & & & & 0,0470 & & & & & & 0,0090 \\
\hline 29 & & & & & & & & & 0,1880 & & & & & & \\
\hline 30 & & & & & & & & & 0,1670 & & & & & & \\
\hline 30.2 & & & & & & & & & 0,0090 & & & & & & \\
\hline 31 & & & & & & & & & 0,0510 & & & & & & \\
\hline 31.2 & & & & & & & & & 0,2090 & & & & & & \\
\hline 32 & & & & & & & & & 0,0040 & & & & & & \\
\hline 32.2 & & & & & & & & & 0,2440 & & & & & & \\
\hline 33.2 & & & & & & & & & 0,0600 & & & & & & \\
\hline 34.2 & & & & & & & & & 0,0090 & & & & & & \\
\hline 35.2 & & & & & & & & & 0,0090 & & & & & & \\
\hline
\end{tabular}

Table 1 - Allelic frequencies of 15 STR in a Bolivian population from La Paz

\begin{tabular}{|c|c|c|c|c|c|c|c|c|c|c|c|c|c|c|c|}
\hline & D851179 & D21S11 & 075820 & CSFIPO & D3S1358 & THO1 & D135317 & D16S539 & D2S 1338 & D195433 & vWA & TPOX & D18551 & 055818 & $\mathrm{FGA}$ \\
\hline$H_{0}$ & 0,76923 & 0,80342 & 0,70085 & 0,68376 & 0,66667 & 0,70085 & 0,78632 & 0,86325 & 0,76923 & 0,73504 & 0,71795 & 0,58120 & 0,85470 & 0,57265 & 0,87179 \\
\hline $\mathrm{H}_{e}$ & 0.78530 & 0.82657 & 0,71610 & 0.70667 & 0,84873 & 0,65544 & 0,79007 & 0,78798 & 0,80305 & 0.79707 & 0.69656 & 0.57861 & 0.85023 & 0,61208 & 0.86629 \\
\hline$\overline{M P}$ & 0,079 & 0,060 & 0,127 & 0,136 & 0.199 & 0,168 & 0.075 & 0,097 & 0,075 & 0.070 & 0.149 & 0.240 & 0,046 & 0,191 & 0.037 \\
\hline $\overrightarrow{P D}$ & 0,921 & 0,940 & 0,873 & 0,864 & 0,801 & 0,832 & 0,923 & 0,903 & 0,925 & 0.930 & 0,851 & 0,760 & 0,954 & 0,809 & 0.963 \\
\hline PIC & 0,750 & 0,800 & 0,660 & 0,660 & 0,580 & 0,610 & 0.760 & 0,750 & 0.780 & 0,760 & 0,640 & 0,530 & 0,830 & 0,580 & 0,850 \\
\hline PE & 0,543 & 0,621 & 0,430 & 0,404 & 0,379 & 0,430 & 0,574 & 0,721 & 0,543 & 0,485 & 0,457 & 0,269 & 0,704 & 0,259 & 0,738 \\
\hline $\begin{array}{l}\text { Pexect test } \\
\text { for Hardy- } \\
\text { Weinberg } \\
\text { equilibrium }\end{array}$ & 0.36616 & 0,41568 & 0,95814 & 0,03677 & 0,18950 & 0,86090 & 0,60668 & 0,05423 & 0,07985 & 0.37811 & 0,89536 & 0,10465 & 0,88244 & 0,13142 & 0.95485 \\
\hline
\end{tabular}

Table 2 - Forensic statistical parameters of La Paz population 